The Lahore Journal of Economics

11 : 1 (Summer 2006) pp. 121-139

\title{
Impact of Exchange Market Forces on Pak-Rupee Exchange Rates during Globalization Period: An Empirical Analysis
}

\author{
Syed Adnan Haider Ali Shah Bukhari", Muhammad Shahbaz \\ Akmal $^{* *}$, Mohammad Sabihuddin Butt
}

\section{Abstract}

This paper analyzes the impact of exchange market forces on PakRupee/US dollar exchange rates during the 1965-1971 globalization period. The main findings are that a) the behavior of Pakistan's fundamentals relative to those of the USA help to explain exchange market forces against the Pak-Rupee; b) during the run up to devaluation in the globalization period the monetary authorities in Pakistan were acting to reduce domestic credit; but that c) additional pressure was brought against the Pak-Rupee from speculative sources. These findings relate to current thinking on the choice of the exchange rate regime as even well behaved fundamentals may not be sufficient to sustain a currency on its peg.

JEL Classification: C53, E58, F31, F33.

Keywords: Exchange market forces, pegged exchange rates, realignment expectations.

\section{Introduction}

This paper offers an investigation of exchange market forces on the Pak-Rupee during the 1965-1971 globalization period, when the Pak-Rupee was pegged to the US dollar through links to real assets. We believe that this investigation is relevant today for what it tells us about the viability of exchange rate pegging.

\footnotetext{
* Corresponding Author: Senior Research Fellow, Faculty of Computer Sciences and I.T. Department of Computer Sciences, FUUAST, Karachi, Pakistan.

${ }^{* *}$ Research Scholar, Associate Professor/Senior Research Economist, Applied Economics Research Centre, Karachi University, Pakistan.

*** Associate Professor/Senior Research Economist, Applied Economics Research Centre, Karachi University, Pakistan.
} 
In the "unholy trinity" of a pegged exchange rate, open capital markets and independent monetary policy, the latter must be largely given up if the former two are to be viable.

It is found that, even though the State Bank of Pakistan seemed to responsibly manage the money base within the confines of the latitude offered by the exchange rate band between the gold points ${ }^{1}$, the PakRupee was still subjected to speculative capital outflows - especially in the four months before it was knocked off its peg during the period of globalization. If this interpretation of our findings is correct, the viability of open capital markets along with pegging is questionable even when the authorities behave responsibly. The issue is whether the State Bank of Pakistan played by the 'rules of the game', by which is usually meant that changes in the money base were strictly determined by the balance of payments. Eichengreen, et. al., (1985) from their empirical evidence argued that the rules were not strictly adhered to as interest rates were sometimes managed, being influenced by the business conditions in the developing countries, and for most of the period under consideration were depressed. The State Bank of Pakistan would cut interest rates in order to stimulate the economy only to have to raise them again to protect the balance of payments and the Pak-Rupee's peg to real assets. In fact, some latitude was afforded to the State Bank of Pakistan by the Pak-Rupee's fluctuation band between the gold points. Lower interest rates could be sustained so long as the exchange rate moved only within the band and did not threaten to breach it.

Figure 1 shows that the Pak-Rupee-dollar exchange rate did indeed fluctuate between estimates of the gold points. This analysis, which estimates an exchange market pressure model, finds that when the State Bank of Pakistan increased the rate of domestic credit expansion, exchange market pressure on the Pak-Rupee-dollar exchange rate would also increase. That is, the exchange rate depreciated within the fluctuation band and foreign exchange reserves fell.

\footnotetext{
${ }^{1}$ The estimated gold points shown in Figure 1 are those of Officer (1993). The gold points were determined by the cost of moving gold across the Atlantic Ocean, and as interest costs were incurred in doing so, the gold points were not constant but fluctuated with interest rates. According to Officer's calculations the gold points averaged about $0.6 \%$ either side of parity.
} 
Figure 1: Pak-Rupee spot exchange rate and estimated gold points

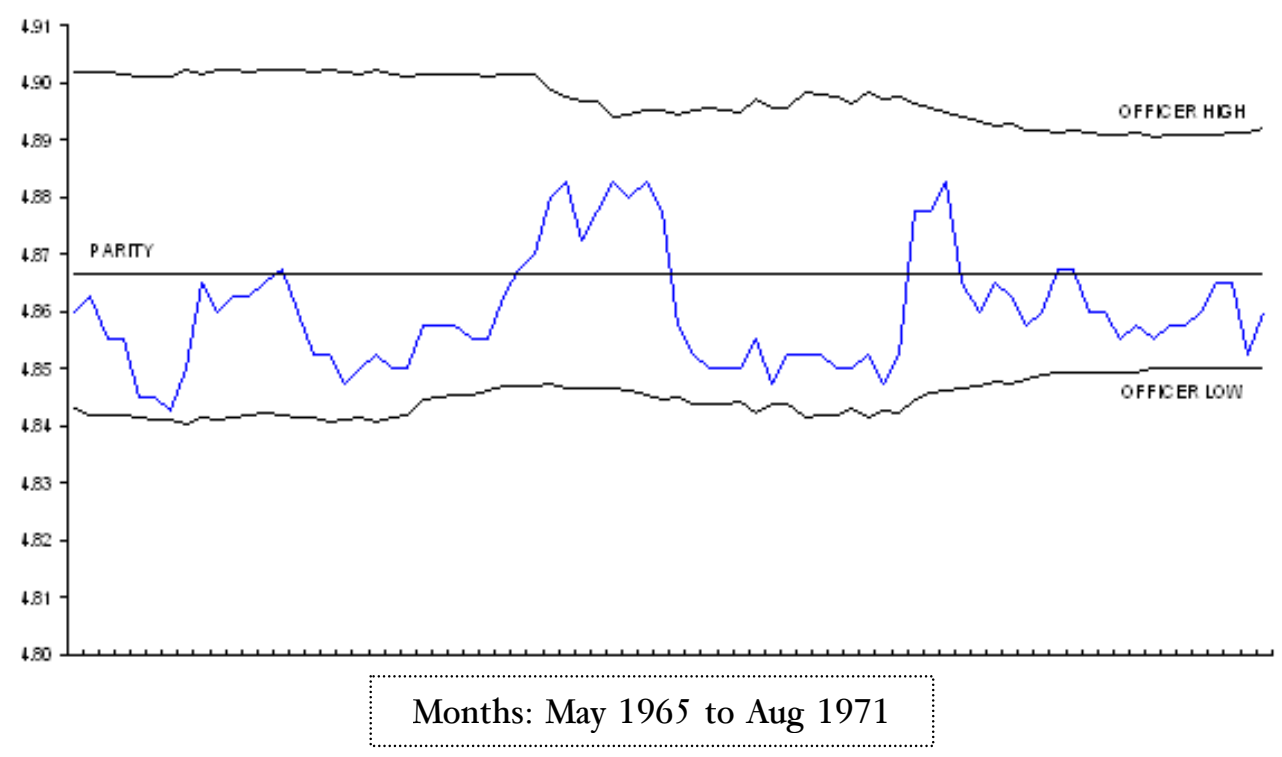

However, we think that the State Bank of Pakistan's monetary policy during this period was in fact well behaved because the peg to gold and the dollar was maintained for more than six years in very difficult world economic circumstances and with an open capital account. Indeed, the experience of the Pak-Rupee during this period was far superior to that of the members of the International Monetary System during the 1990s when currency realignments were very frequent even though exchange rate fluctuation bands were relatively wide and capital accounts were not necessarily fully open. Another strand of evidence that supports the view that the State Bank of Pakistan was conservative in its management of the money base comes from our calculation of the Pak-Rupee-dollar realignment expectations in the foreign exchange market. We show that between the Pak-Rupee's return to the gold standard in this period the market did not expect the Pak-Rupee to be devalued. Our empirical evidence is based on the target zone model of Krugman (1988 and 1991) as extended by Svensson $(1991,1993)$ and Bertola and Svensson (1993) and is described in Section 2 below. However, in the globalization period, devaluation expectations turned strongly against the Pak-Rupee, in the sense that they became statistically significant and larger than at any other time during the previous years. But why did this run on the Pak-Rupee occur when it did? We found that over the period as a whole, exchange rate expectations did affect current Pak-Rupee-dollar exchange rate movements within the band, and that in the last three months of the regime the markets were expecting a devaluation of the central parity. However, on the evidence that we are 
able to present we do not assume that this speculative attack against the Pak-Rupee was by any means entirely provoked by the State Bank of Pakistan's management of the money base. Indeed, the money base had increased by only four percent in the first six months of the year - hardly a runaway rate of expansion and, as is shown below, during the seven months before the globalization-period devaluation of the Pak-Rupee, the State Bank of Pakistan's management of domestic credit was helping to reduce exchange market pressure on the Pak-Rupee.

The paper proceeds as follows: in Section 1 a model is developed to explain exchange market forces against the Pak-Rupee. Section 2 discusses how the Krugman $(1988,1991)$ target zone model, as extended by Svensson (1991 and 1993) and Bertola and Svensson (1993), can be used to reveal realignment expectations during Pakistan's gold standard pegging episode of the pre-globalization period. These realignment expectations are used in section 3 as an independent variable and are shown to contribute to exchange market pressure against the Pak-Rupee along with the macroeconomic and monetary variables derived from the exchange market pressure model. Conclusions are drawn in Section 4.

\section{Exchange market forces and the Pak-Rupee}

The exchange market pressure model is a natural development out of the monetary approach to the balance of payments and the monetary approach to the exchange rate. The two fundamental assumptions of these models are that agents have desired levels of real money balances, and that while the balance of payments is made up of three sub-accounts - goods, capital and money - which sum to zero, the analytical emphasis is on the monetary account. The two central equations of these models are pairs of money demand and money supply functions, one for each country in a twocountry world. Money demand is a standard function of real income, prices and nominal interest rates, and the domestic money supply is backed by domestic assets and gold and foreign exchange acquired over time through central bank foreign exchange intervention. ${ }^{2}$

\footnotetext{
${ }^{2}$ We choose not to use the Eichengreen, Rose and Wyplosz (1996) measure of exchange market forces because questions have been raised about its theoretical basis. These questions concern the (non-unitary) weights used in their calculation of an index of exchange market pressure. Weymark (1998) says that their index is not satisfactory because it lacks a rigorous theoretical basis, and it "cannot be interpreted as a cardinal (or even ordinal) measure of speculative pressure" ( $p$ 118). Spolander calls their measure "ad hoc" (1999, p 17), and Peltonen says that their weights are "arbitrarily chosen" (2002, p 12). In this paper, as in Girton and Roper (1977) and as recently as Tanner
} 
What Girton and Roper (1977) did in their seminal paper on exchange market pressure (and extended by Weymark, 1995, 1998) combined the monetary approaches to the balance of payments and to the exchange rate into a single model. Thus, if an exchange rate is allowed to move within a fluctuation band (or, target zone), taken separately, neither the movement of the exchange rate nor the movement of foreign exchange reserves will necessarily give an accurate measure of exchange market pressure. For example, the exchange rate could be steady or even appreciating, while foreign exchange reserves were falling rapidly. However, taken together, movements in rates and reserves can be used to indicate exchange market pressure.

The Girton and Roper model of foreign exchange market flow equilibrium can be expressed in logarithmic changes as:

$$
\begin{array}{ll}
\Delta m_{t}^{s}=\Delta d_{t}+\Delta f_{t} & \Delta m_{t}^{* s}=\Delta d_{t}^{*}+\Delta f_{t}^{*} \\
\Delta m_{t}^{d}=\Delta p_{t}+\beta \Delta y_{t}-\alpha \Delta i_{t} & \Delta m_{t}^{* d}=\Delta p_{t}^{*}+\beta \Delta y_{t}^{*}-\alpha \Delta i_{t}^{*} \\
\Delta p_{t}=\Delta p_{t}^{*}+\Delta s_{t}+\theta_{t} & \\
\Delta i_{t}=\Delta i_{t}^{*}+\delta_{t} &
\end{array}
$$

Variables with an asterisk signify US variables and those without an asterisk, domestic country variables. Equation (1) sets the growth in the supply of base money $\left(\Delta m_{t}^{s}\right)$ equal to the sum of domestic credit expansion $\left(\Delta d_{t}\right)$ and the growth of foreign exchange reserves $\left(\Delta f_{t}\right)$. Equation (2) describes the growth of demand for nominal domestic money balances $\left(\Delta m_{t}^{d}\right)$ in terms of growth in domestic prices $\left(\Delta p_{t}\right)$, real income $\left(\Delta y_{t}\right)$ and an appropriate index of nominal interest rates $\left(\Delta i_{t}\right)$. Equivalent money supply and demand relationships hold for the USA. The income elasticity of demand for money is $\beta$, and the interest semi-elasticity of demand for money is $\alpha$. Equation (3) allows relative purchasing power parity to hold continuously if the real exchange rate, $\theta_{t}$, is forced equal to zero. However, variations of the real exchange rate from zero means that purchasing power parity does not hold exactly. Note that the nominal exchange rate (the price of the dollar in terms of Pak-Rupee) is defined

(2001), the weights applied to the left-hand-side variables in equation (5) below are indeed unity. Tanner (2001, p 315, footnote 15) says that this is acceptable if, as here, a standard monetary model is used. Tanner (2001) also notes that Eichengreen, Rose and Wyplosz (1996) do not use a standard monetary model. 
such that a positive value of $\Delta s_{t}$ represents the rate of depreciation of the Pak-Rupee. Equation (4) simply sets $\delta_{t}$ equal to the change in the interest rate differential. ${ }^{3}$ Svensson (1993, page 766) pointed out that the interest differential may combine both exchange rate expectations and a risk premium - an increase in the differential indicating some combination of (a) increased expectations of depreciation and (b) a greater premium attached to that risk. In common with most papers in this area we will continue to regard the interest differential as indicating just expectations of future exchange rate changes because whichever component increases, pressure on a currency will increase as investors readjust their portfolios against it.

An issue is how to measure exchange market pressure (EMP) against a currency. Weymark (1998) develops a model-independent formula to calculate exchange market pressure that could be applicable to virtually any exchange rate model, such as the monetary-asset approach being used in this paper. EMP defined as the total excess demand for a currency and can be measured by the exchange rate change which would have been required to remove the excess demand in the absence of money or foreign exchange market intervention, given that expectations are generated by the exchange policy actually implemented. However, since this definition of EMP is unobservable (because the authorities usually do intervene in the markets, particularly in the period under examination here), it needs to be made operational, and that requires a model.

Weymark (1998) argues that model-specific measures of EMP should conform to her model-independent definition. In general, this independent measure is stated as the expected change in the exchange rate plus the weighted change in foreign exchange reserves. ${ }^{4}$ The magnitude of the weight may have to be econometrically estimated from a structural model of a macro-economy. ${ }^{5}$

Some manipulation of equations (1)-(4) yields:

$$
\Delta f_{t}-\Delta f_{t}^{*}-\Delta s_{t}=-\Delta d_{t}+\Delta d_{t}^{*}+\beta\left(\Delta y_{t}-\Delta y_{t}^{*}\right)+\theta_{t}-\alpha \delta_{t}
$$

\footnotetext{
${ }^{3}$ Weymark (1998) discusses the role of exchange rate expectations in the derivation of model-consistent exchange market pressure indices. Thus, static exchange rate expectations would mean $\delta^{t}$ represents changes in the risk premium implicit in domestic interest rates.

${ }^{4}$ This assumes that changes in domestic credit are not an instrument of exchange rate policy.

${ }^{5}$ Spolander (1999) includes a very detailed discussion of this process.
} 
The composite dependent variable in equation (5) is the GirtonRoper model-specific measure of exchange market pressure (where the weight on reserve changes is unity). A lower numerical value of this EMP measure signifies greater pressure against the State Bank of Pakistan because there is some combination of a decline in the rate of growth of Pakistan foreign exchange reserves relative to reserve growth in the USA and a rise in the rate of the Pak-Rupee's depreciation (a rise in $\Delta s_{t}$ ). According to the mode1, EMP against the Pak-Rupee increases with an increase in Pakistan's rate of domestic credit expansion, or its rate of interest (i.e. $\delta_{t}$ increases), or with a decrease in the real exchange rate. Pressure diminishes with an increase in the rate of growth of Pakistani real income relative to that of the USA. Weymark (1998) showed that the Girton and Roper (1977) modelspecific formula for exchange market pressure that we employed does conform to her model-independent formula. Tanner (2001) is in agreement with this.

\section{Revealing realignment expectations}

If an exchange rate is to be confined to a target zone, financial markets need to believe that the authorities are willing to defend that zone otherwise international capital flows will destroy the peg. Thus, monetary policy must be used to defend the parity. The exchange rate is determined as:

$$
s_{t}=m_{t}^{s}+v_{t}+\alpha E_{t}\left[d s_{t}\right] / d t
$$

As earlier, in natural logarithms, $s_{t}$ is the domestic currency price of foreign exchange, $m_{t}^{s}$ is the money supply, and $\alpha$ is the semi-elasticity of demand for money. The term $v$ is a general purpose term that includes anything else that impacts the demand or supply for money (e.g. changes in real income). Most simply, $v$ is taken to be the cumulative value of velocity (Miller and Weller, 1991). Shocks to velocity are assumed to be random with zero mean, and to be normally distributed such that the cumulative value of $v$ follows a continuous-time random walk. The term $E_{t}\left[d s_{t}\right] / d t$, is the instantaneous rationally expected rate of change of the exchange rate.

To maintain credibility, an exogenous shock to fundamentals such as a fall in real economic activity that would otherwise push the exchange rate outside the target zone must be offset by a monetary contraction - for instance, by open market sales of domestic securities or a rise in the discount rate. At the edges of the target zone monetary policy must be geared exclusively to the exchange rate and not, say, towards influencing 
business conditions. But when the exchange rate is in the interior of the zone the monetary authorities do have some freedom of action. The domestic interest rate can differ from the foreign interest rate provided that the indicated exchange rate expectation is not forced outside the intervention points.

A measure of realignment expectations has been developed in Svensson (1991, 1993), and Bertola and Svensson (1993). Thus, in natural logarithms at time $t$ the nominal exchange rate, $s_{t}$, is:

$$
s_{t}=x_{t}+c_{t}
$$

where $c_{t}$ is the central parity and $x_{t}$ is the proportionate deviation from parity. Taking time derivatives:

$$
E_{t}\left[d s_{t}\right] / d t=E_{t}\left[d x_{t}\right] / d t+E_{t}\left[d c_{t}\right] / d t
$$

Equation (8) says that the rationally expected rate of change of the exchange rate can be divided into the expected movement 'within the band', $E_{t}\left[d x_{t}\right] / d t$, plus the expected rate of depreciation of the central parity, $E_{t}\left[d c_{t}\right] / d t$. Furthermore, for any given $x_{t}$, movement within the band is bounded by the lower ("strong") gold import point and upper ("weak") gold export point.

$$
\left(x_{t}^{l}-x_{t}\right) / d t \leq E_{t}\left[d x_{t}\right] / d t \leq\left(x_{t}^{u}-x_{t}\right) / d t
$$

where $x^{l}$ is the lower bound of $s_{t}$, and $x^{u}$, the upper bound.

On using equations (8) and (9) the confidence interval for realignment expectations is:

$$
\left(i_{t}-i_{t}^{*}\right)-\left(x_{t}^{u}-x_{t}\right) / d t \leq E_{t}\left[d c_{t}\right] / d t \leq\left(i_{t}-i_{t}^{*}\right)-\left(x_{t}^{l}-x_{t}\right) / d t
$$

where as, $i_{t}$ is the home country's interest rate and $i_{t}^{*}$ is a comparable interest rate in the foreign country. The term $\left(i_{t}-i^{*}\right)$ has been substituted for $E_{t}\left[d s_{t}\right] / d t$ because we are assuming that uncovered interest parity holds. Thus, equation (10) defines the minimum and maximum bounds of the market's rationally expected rate of realignment of the central parity (a $100 \%$ confidence interval, assuming the gold points are known with certainty). 
Rearranging equation (8) obtains a statement of the rationally expected realignment expectation as:

$$
E_{t}\left[d c_{t}\right] / d t=E_{t}\left[d s_{t}\right] / d t-E_{t}\left[d x_{t}\right] / d t
$$

This realignment expectation can be calculated if the two terms on the right hand side are known. The total expected change in the exchange rate, $E_{t}\left[d s_{t}\right] / d t$, is known from the interest differential. Svensson (1993) details a simple but robust method for calculating the expected movement of the exchange rate within the band. He takes this to be a linear function of the current deviation of the exchange rate from the central parity, $x_{t}$, such that the expected movement of the exchange rate within the band is empirically estimated as the fitted value from the following regression:

$$
x_{t+m}-x_{t}=a_{0}+a_{1} x_{t}+u_{t}
$$

In this unit root test, mean reversion is occurring if $a_{1}$ is significantly less than zero. ${ }^{6}$

Implementing equation (12) using the Pak-Rupee-dollar exchange rate data for the globalization period, we found evidence, reported in Table1 , of mean reversion within the band of the Pak-Rupee-dollar exchange rate. The regression is conducted with $m$ set equal to three months to match the maturity of the forward rate contracts used later in this paper. This choice of $m$ induces second order serial correlation in the equation so all statistics are computed using Newey-West generalized method of moments estimators (see Sarno and Taylor, 2002).

\footnotetext{
${ }^{6}$ The percentage value of a realignment expectation at any time, $t$, is equal to the product of the probability of devaluation and the size of the devaluation. Our exchange market pressure economic model attempts to explain this product, not either component of it. Svensson's drift adjustment method used here assumes that the probability of devaluation is exogenous to the model. Further development of target zone theory by Mizrach (1995) shows that as the probability of devaluation can be recovered from the data there is no need to make the restrictive exogeneity assumption. Indeed, following Hallwood, MacDonald and Marsh (2000) we have done just this - recovered endogenous dollarRupee devaluation probabilities. However, for this paper the criticism of exogeneity is not relevant because we are trying to explain realignment expectations as a whole. Furthermore, models that use the exogenous probability of devaluation assumption have an excellent record in correctly forecasting devaluation events (see Svensson, 1993), and this is also true in this paper for "predicting" the September 1971 devaluation of the PakRupee. Moreover, in the work of Darvas (1998) Monte Carlo simulations show that the drift adjustment method performs well in reproducing the stylized facts of exchange rate behavior in a target zone.
} 
It is perhaps not surprising to find mean reversion in an exchange rate that in fact remained within its band for as long as six years. However, it could be noted that mean reversion is not inevitable. A currency could move to an intervention point and then just bump along there without reverting to the center of its band. Rather, the finding of mean reversion indicates that the market indeed had confidence in the Pak-Rupee. Certainly, a lower relative Pakistan price level might have eased the State Bank of Pakistan's job of keeping the Pak-Rupee on gold by giving it greater freedom to reduce interest rates, thereby allowing some stimulus to the depressed Pakistan economy. However, the fact of the matter is that notwithstanding the depressed Pakistan economy, the State Bank of Pakistan was prepared to manage interest rates to keep the Pak-Rupee on gold.

The final step in implementing equation (11) is to take the $95 \%$ confidence intervals for mean reversion calculated using equation (12), and to combine them with the interest rate differential data, which proxy for $E_{t}\left[d s_{t}\right] / d t$, to calculate $95 \%$ confidence intervals for realignment expectations.

We reproduce our calculations of monthly realignment expectations for the Pak-Rupee-dollar exchange rate May 1965 to August 1971 in Figure 2. When the upper and lower bounds for realignment expectations are on different sides of the zero line (or x-axis) realignment expectations are not statistically significant. That is, there is no strong evidence of speculation against the Pak-Rupee. However, things were very different in the summer of 1971 when realignment expectations turned strongly against the PakRupee (the upper and lower bounds of realignment expectations were both positive). This provoked capital outflows from Pakistan, exerting exchange market pressure against it, so much so that the Pak-Rupee was to be bumped off its gold-dollar peg.

\section{Empirical results revealing exchange market pressure}

But what was the cause of exchange market pressure against the PakRupee? To investigate this question we implemented equation (5) which shows that exchange market pressure is being determined by macroeconomic variables and a monetary variable, the rate of domestic credit expansion that was under the direct control of the State Bank of Pakistan.

Equation (5) is tested using monthly data for the 1965-1971 period. Since reliable contemporaneous quotations of interest rates of the same 
maturity are hard to find for this period we assume covered interest parity holds and use the forward premium/discount as our measure of the interest differential. ${ }^{7}$

The equations presented in Table- 3 were estimated using the McCallum-Wickens instrumental variables technique. ${ }^{8}$ In each case the dependent variable is exchange market pressure and the exchange rate is the Pak-Rupee-dollar rate. The instrument set is the dependent and each explanatory variable lagged by two and three periods, together with a constant and a time trend. The figures in parentheses under the coefficient estimates are $t$-statistics computed with Newey-West GMM standard errors, robust to serial correlation and heteroskedasticity.

Column A of Table-3 details the results of the most rigid interpretation of equation (5). The coefficient on Pakistan domestic credit growth is statistically significant, correctly signed and not far from its theoretical value of minus unity (a test of this restriction cannot be rejected - see $H 1^{9}$ ). US domestic credit growth and relative income growth rates are both insignificant (though correctly signed). The coefficient on the real exchange rate term is negative and therefore carries the wrong sign. ${ }^{10}$ Finally, the coefficient on the change in our proxy for the interest differential, $\delta$, is also significant and correctly signed. Column B of Table-3 loosens the restriction that the income elasticity of demand for money is

\footnotetext{
${ }^{7}$ Covered interest parity holds when $\mathrm{i}=\mathrm{i}^{*}+(\mathrm{F}-\mathrm{S}) / \mathrm{S}$ where $\mathrm{i}$ is a short-term rate of interest, $\mathrm{S}$ is the spot exchange rate, $\mathrm{F}$ the forward exchange rate of the same maturity as $i$ and the asterisk signifies the foreign country. In a liquid foreign exchange market $F=S^{e}$ where $S^{\mathrm{e}}$ is the expected future spot exchange rate. When this condition holds $\mathrm{S}^{\mathrm{e}}$ can be substituted for $\mathrm{F}$ - i.e. uncovered interest parity and covered interest parity hold simultaneously. Whether covered interest parity held during the inter-war period has been tested by Peel and Taylor (2002) who find a larger 'neutral' zone (i.e. profit opportunities that are not arbitraged) than is common today. Their preferred explanation for this is that markets were not inefficient but that the opportunity costs of arbitrage were higher then than they are today.

${ }^{8}$ An estimator is used with the instruments carefully chosen so as not to introduce a moving average error process into the residuals.

${ }^{9}$ Possibly because they are measured with error, more so than the other variables.

${ }^{10}$ The negative sign on the real exchange rate has an interesting theoretical implication. In the monetary model used here a rise in Pakistan's price level, thereby raising the value of the real exchange rate, increases the demand for money in Pakistan which is satisfied by an increase in foreign exchange reserves. This explains the $+\theta$ in equation 5 . However, this money market stock adjustment mechanism could be dominated by the adverse affect of a higher Pakistan price level on Pakistan's current account that would increase exchange market pressure against the Pak-Rupee.
} 
equal in the two countries. ${ }^{11}$ Here the coefficient on US (Pakistan) income growth is significantly positive (insignificantly negative).

In columns $\mathrm{C}$ and $\mathrm{D}$ we decompose changes in the interest rate differential proxy into changes in the expected movement of the exchange rate within the band, $\Delta E\left[d x_{t}\right] / d t$, and changes in the expected rate of devaluation of the Pak-Rupee, $\Delta E\left[d c_{t}\right] / d t$, based on equation (8). Both these factors are expected to affect exchange market pressure on the State Bank of Pakistan, though perhaps not equally. With equal and opposite signs imposed on income growth in the two countries (column C), the two new terms are both negative and statistically significant while the other coefficient estimates are essentially unchanged from the baseline regression in column A.

Removing the restriction on income growth we obtain the results in column D. The adjusted coefficient of determination is highest in this version of the model while the standard error of the equation is the lowest, suggesting this to be the statistically preferred specification. Coefficient estimates are little changed from the regression in column B. Thus, an increase in Pakistan's rate of domestic credit expansion, $\Delta d_{t}$, increases exchange market pressure, as does faster economic growth in the US. The rate of US domestic credit expansion has the correct sign but is insignificant in every specification of the regression. Perhaps this is due to the well known fact that during the period the USA was not playing by the rules of the game since it was sterilizing the effect of its payments surpluses on its money base.

What is most interesting about this last regression is the correct and significant signs on $\Delta E\left[d x_{t}\right] / d t$ and $\Delta E\left[d c_{t}\right] / d t$. Significantly, an increase in realignment expectations, $\Delta E\left[d c_{t}\right] / d t$, increased pressure against the PakRupee. This pressure, according to the definition of EMP, takes the form of depreciation of the Pak-Rupee within the band, or a reduction in foreign exchange reserves to protect the Pak-Rupee, or both. What is happening is that a rise in $E\left[d c_{t}\right] / d t$ - an increase in either the probability or the magnitude of the expected devaluation of the Pak-Rupee - is encouraging capital outflows which in turn put pressure on the State Bank of Pakistan to intervene. Importantly, this speculative pressure is additional to the pressure exerted by the fundamental variables in the regression equation; the rates of

\footnotetext{
${ }^{11} \mathrm{We}$ would have also liked to relax the assumption that the interest semi-elasticities are equal in the two countries, however since we do not have reliable interest rate data and are instead using the forward premium to measure the spread, this is not possible.
} 
domestic credit expansion and real income growth in Pakistan and the USA, and the real exchange rate.

Figure 3 plots the contributions to exchange market pressure from the significant terms in the final specification of our estimation (column D). The solid line shows the dependent variable, EMP. The pressure on the PakRupee in that period was such that EMP took four of its five lowest values. Focusing on the period after globalization several points are noticeable. First, domestic credit growth in Pakistan and the US were always acting to reduce exchange market pressure on the Pak-Rupee (the relevant bars are always positive in the final twenty months of the peg). Conversely, the real exchange rate is always adding to the pressure. The remaining two terms changes in the expected reversion within the band and changes in the expected devaluation - regularly switch signs. Most significantly, however, in the critical final two months of the peg devaluation expectations were adding hugely to the pressure on the Pak-Rupee. Indeed, if we exclude the effect of changes in devaluation expectations, pressure would have turned positive on it and been only slightly negative after it.

\section{Conclusions}

Our main finding is that exchange market forces against the PakRupee while it was operating a peg to gold and through it to the US dollar during the 1965-1971 period is quite well explained by the models that we used. Furthermore, we found that devaluation expectations had statistically and economically significant explanatory power in addition to the behavior of the fundamentals of the Pakistan economy. The main implication of this latter finding is that disciplined management of fundamentals even over a minimum period of time may not be enough to maintain a currency peg. As capital outflows from Pakistan during this period were not necessarily driven by fundamentals, perhaps the peg could have been saved by the imposition of capital controls. Put differently, we found that the "unholy" trinity of a pegged exchange rate, open capital markets and an independent monetary policy may not be viable even when monetary policy appears to be disciplined. Therefore, such an unfortunate experience is relevant to the choice of an exchange rate regime for a country like Pakistan. 
134 Syed Adnan Haider Ali Shah Bukhari, M. Shabbaz Akmal, M. Sabihuddin Butt

Appendix-A

Table-1: Expected change of the exchange rate within globalization period

\begin{tabular}{lc}
\hline Constant & 0.854 \\
& $(1.860)$ \\
$\mathrm{X}$ & -0.622 \\
& $(3.53)$ \\
$\mathrm{R}^{2}$ & 0.810 \\
Standard error & 0.00197 \\
\hline
\end{tabular}

Notes: Monthly data. Figures in parentheses are $\mathrm{t}$ statistics computed with GMM standard errors to account for serial correlation induced by the overlapping observations. The Dickey-Fuller test is of the hypothesis that $\alpha=0$. As the DF $5 \%$ significance critical value is 2.076 we accept that $\alpha$ is negative.

Table-2: Descriptive Statistics

\begin{tabular}{lccr}
\hline Series & Mean & Min & \multicolumn{1}{c}{ Max } \\
\hline Change in Pakistan reserves & $0.03 \%$ & $-0.39 \%$ & $0.47 \%$ \\
Change in US Reserves & $1.88 \%$ & $-15.14 \%$ & $17.29 \%$ \\
Change in Pakistan domestic credit & $-1.03 \%$ & $-4.10 \%$ & $7.27 \%$ \\
Change in US domestic credit & $-1.59 \%$ & $-38.03 \%$ & $62.07 \%$ \\
Change in Pakistan industrial prod & $-5.03 \%$ & $-236.82 \%$ & $260.19 \%$ \\
Change in US industrial prod & $-2.39 \%$ & $-26.18 \%$ & $21.14 \%$ \\
Pakistan inflation & $-5.83 \%$ & $-21.87 \%$ & $5.99 \%$ \\
US inflation & $-2.27 \%$ & $-6.78 \%$ & $0.91 \%$ \\
\hline
\end{tabular}

Notes: All values given in annualized percentage form.

\section{Data collected from:}

Various Survey Reports, State Bank of Pakistan

Pakistan Economics Survey Reports, Ministry of Finance, Government of the Pakistan, Various annual Issues International Financial Statistics, various issues 
Table-3: Exchange market forces on the Pak-Rupee-dollar exchange rate in Globalization Period

\begin{tabular}{|c|c|c|c|c|}
\hline & (A) & (B) & (C) & (D) \\
\hline Constant & $\begin{array}{l}-0.001 \\
(1.177)\end{array}$ & $\begin{array}{l}-0.0001 \\
(0.132)\end{array}$ & $\begin{array}{l}-0.001 \\
(1.256)\end{array}$ & $\begin{array}{l}-0.0002 \\
(0.327)\end{array}$ \\
\hline$\Delta \mathrm{d}$ & $\begin{array}{l}-1.240 \\
(2.195)^{*}\end{array}$ & $\begin{array}{l}-1.366 \\
(2.408)^{* *}\end{array}$ & $\begin{array}{l}-1.398 \\
(2.431)^{* *}\end{array}$ & $\begin{array}{l}-1.460 \\
(2.822)^{* *}\end{array}$ \\
\hline$\Delta d$ & $\begin{array}{c}0.083 \\
(0.716)\end{array}$ & $\begin{array}{c}0.069 \\
(0.538)\end{array}$ & $\begin{array}{c}0.095 \\
(0.798)\end{array}$ & $\begin{array}{c}0.101 \\
(1.001)\end{array}$ \\
\hline$\Delta y-\Delta y^{*}$ & $\begin{array}{c}0.001 \\
(0.032)\end{array}$ & & $\begin{array}{l}-0.003 \\
(0.798)\end{array}$ & \\
\hline$\Delta y$ & & $\begin{array}{c}0.009 \\
(0.351)\end{array}$ & & $\begin{array}{c}0.002 \\
(0.117)\end{array}$ \\
\hline$\Delta y^{*}$ & & $\begin{array}{l}-0.306 \\
(1.996)^{*}\end{array}$ & & $\begin{array}{l}-0.272 \\
(1.980)^{*}\end{array}$ \\
\hline$\Theta$ & $\begin{array}{l}-0.416 \\
(2.883)^{* *}\end{array}$ & $\begin{array}{l}-0.824 \\
(3.404)^{* *}\end{array}$ & $\begin{array}{l}-0.501 \\
(3.466)\end{array}$ & $\begin{array}{l}-0.849 \\
(4.157)^{* *}\end{array}$ \\
\hline$\Delta$ & $\begin{array}{l}-9.086 \\
(3.524)^{* *}\end{array}$ & $\begin{array}{l}-9.477 \\
(3.692)^{* *}\end{array}$ & & \\
\hline$\Delta E[d x] / d t$ & & & $\begin{array}{l}-2.300 \\
(4.542)^{* *}\end{array}$ & $\begin{array}{l}-2.087 \\
(5.375)^{* *}\end{array}$ \\
\hline$\Delta E[d c] / d t$ & & & $\begin{array}{l}-1.690 \\
(2.472)^{* *}\end{array}$ & $\begin{array}{l}-1.797 \\
(2.445)^{* *}\end{array}$ \\
\hline $\operatorname{Adj}-R^{2}$ & 0.053 & 0.002 & 0.192 & 0.304 \\
\hline Standard error & 0.0055 & 0.0057 & 0.0051 & 0.0047 \\
\hline Q-statistic & 22.61 & 17.18 & 29.40 & 23.64 \\
\hline P-value & 0.26 & 0.58 & 0.06 & 0.21 \\
\hline$H 1 \Delta d=-1$ & 0.67 & 0.52 & 0.49 & 0.37 \\
\hline $\begin{array}{l}H 2 \Delta d=-1 \\
\text { and } \Delta d^{*}=1\end{array}$ & 0.00 & 0.00 & 0.00 & 0.00 \\
\hline
\end{tabular}

Notes: $\Delta d$ denotes the growth of domestic credit (domestic credit defined as base money less reserves), and $\Delta y$ denotes the growth in income as proxied by industrial production. An asterisk denotes a foreign (US) variable. 
$\theta$ is Pakistan's real exchange rate, and $\delta$ denotes the growth in the interest rate differential as proxied by the forward premium. $\Delta E\left[d x_{t}\right] / d t$ and $\Delta E\left[d c_{t}\right] / d t$ denote respectively changes in the expected movement of the exchange rate within the band and changes in devaluation expectations. The figures in parentheses beneath the parameter estimates are $t$-statistics derived using GMM standard errors robust to serial correlation and heteroskedasticity* significant at the 5\% leve1.** significant at the $1 \%$ level. Some descriptive and diagnostic statistics are reported beneath the parameter estimates. Adj- $\mathrm{R}^{2}$ gives the adjusted coefficient of determination. The next row gives the standard error of the estimated equation. Q-statistic denotes the Q-test for serial correlation of up to 19 lags, and the P-value statistic gives the significance level of the Q-statistic. The figures $H 1-H 2$ denote the significance of chi-squared tests of coefficient restrictions. $H$ imposes the constraint that the coefficient on the growth of domestic credit is -1 . $H 2$ imposes the restrictions that the coefficients on Pakistan and US domestic credit growth are equal to -1 and +1 respectively. 


\section{Appendix-B}

Figure 2: Estimated realignment expectation 95 percent confidence intervals

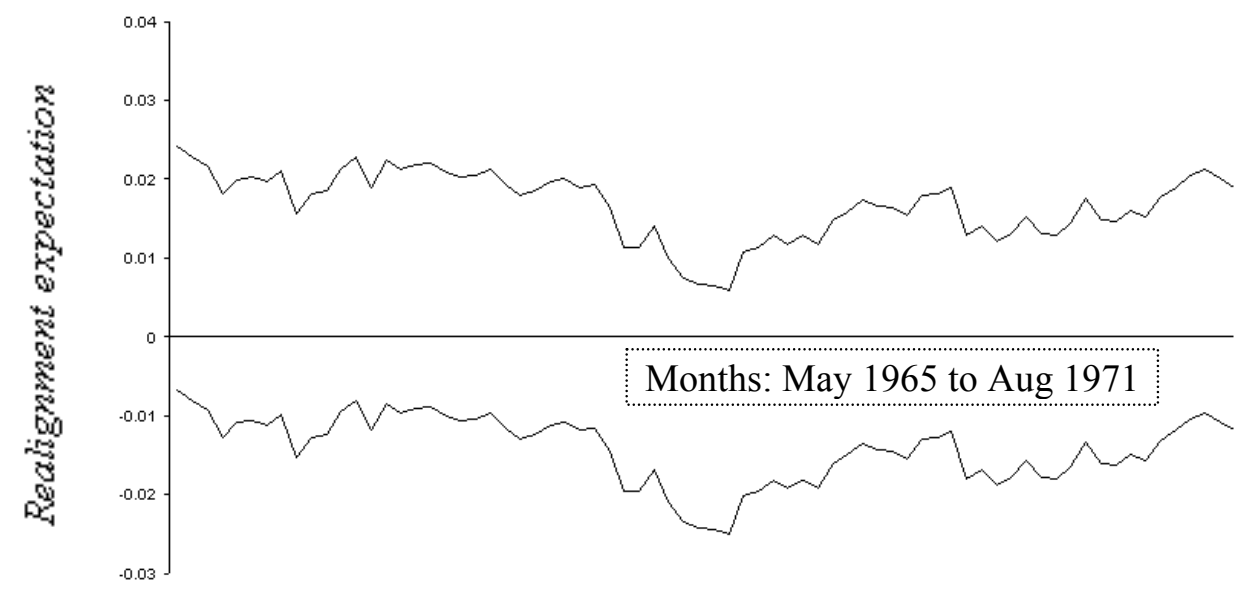

Note: Vertical axis: Calculated realignment expectation - multiply by 100 to obtain in percentage terms. Realignment expectation $=$ size of exchange rate change multiplied by the probability of occurrence.

Figure-3: Contributions to exchange market forces

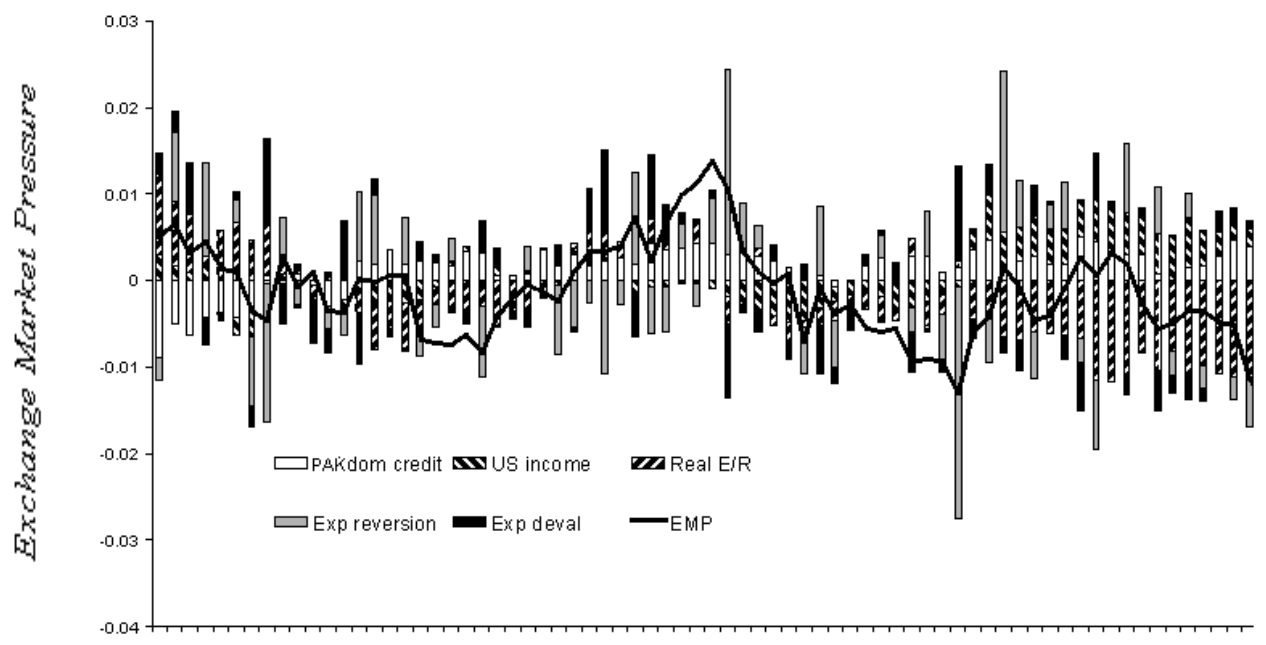

Months: May 1965 - August 1971

Note: see equation 5 


\section{References}

Alam, S. Butt, M. S. and Iqbal, A. 2002, "The Long-Run Relationship between Real Exchange Rate and Interest Rate in Asian Countries: An Application of Pane1 Cointegration”, Pakistan Development Review, 40:4, Part II, 577-602.

Bertola, G. and Svensson, L.E.O. 1993, "Stochastic Devaluation Risk and the Empirical Fit of Target-Zone Models”, Review of Economic Studies, 60, 689-712.

Capie, F. and Webber, A. 1985, A Monetary History of the United Kingdom, 1870-1982, volume 1, Data Sources, and Methods, London, Allen and Unwin.

Cairncross, A. and Eichengreen, B. 1983, Sterling in Decline: the devaluations of 1931, 1949 and 1967, Blackwell, Oxford.

Darvas, Z. 1998, "Spurious Correlation in Exchange Rate Target Zone Modeling: Testing the Drift Adjustment Method on the US Dollar, Random Walk and Chaos”, CEPR, Discussion Paper 1890.

Eichengreen, B. Rose, A. and Wyplosz C. 1996, "Speculative Attacks on Pegged Exchange Rates: an Empirical Exploration with Special Reference to the European Monetary System”, in M.B. Canzoneri, W.J. Eithier and V. Grilli (eds), The New Transatlantic Economy, Cambridge University Press, Cambridge.

Eichengreen, B. 1992, Golden Fetters: The Gold Standard and the Great Depression, 1919-1939, Oxford University Press, Oxford.

Einzig, P. 1937, The Theory of Forward Exchange, MacMillan, London.

Federal Reserve Board, Board of Governors of the 1943, Banking and Monetary Statistics, 1914-1941, Washington D.C.

Hallwood, P. MacDonald, R. and Marsh, I.W. 2000, "Realignment Expectations and the US Dollar: Was there a Peso Problem?" Journal of Monetary Economics, 46, 605-620.

Krugman, P. R. 1988, "Target Zones and Exchange Rate Dynamics”, NBER Working Paper 2481, Cambridge MA. 
Krugman, P.R. 1991, "Target Zones and Exchange Rate Dynamics", Quarterly Journal of Economics, CVI (3), 669-682.

Miller, M. and Weller, P. 1991, "Currency Bands, Target Zones and Price Flexibility”, IMF Staff Papers, 38, 184-215.

Mizrach, B. 1995, "Target Zone Models with Stochastic Realignments: An Econometric Evaluation”, Journal of International Money and Finance, 14 (5), 641-57.

Officer, L. 1993, "Gold-Point Arbitrage and Uncovered Interest Arbitrage Under the 1925-31 Dollar-Sterling Gold Standard”, Explorations in Economic History, 30, 98-127.

Pee1, D.A. and Taylor, M.P. 2002, "Covered Interest Rate Arbitrage in the Interwar Period and the Keynes-Einzig Conjecture”, Journal of Money and Credit and Banking, 34(1), 51-75.

Sarno, L. and Taylor, M. 2002, The Economics of Exchange Rates, Cambridge University Press, Cambridge.

Spolander, M. 1999 "Measuring Exchange Market Pressure and Central Bank Intervention”, Bank of Finland Studies E:17.

Svensson, L.E.O. 1991, "The Simplest Test of Target Zone Credibility”, IMF Staff Papers, 38, 655-65.

Svensson, L.E.O. 1993, “Assessing Target Zone Credibility: Mean Reversion and Devaluation Expectations in the ERM: 1979-1992”, European Economic Review, 37, 763-802.

Tanner, E. 2001, "Exchange Market Pressure and Monetary Policy: Asia and Latin America in the 1990s”, IMF Staff Papers, 47 (3), 311-333.

Weymark, D.N. 1995, "Estimating Exchange Market Pressure and the Degree of Exchange Market Intervention for Canada”, Journal of International Economics, 39, 249-72.

Weymark, D.N. 1998, “A General Approach to Measuring Exchange Market Pressure”, Oxford Economic Papers, 50, 106-21. 